\title{
Bir Eylem Etiği Teorisine Doğru: İlkesel Muhafazakârlığın Eleştirisi
}

\section{HÜSEYIN DENIZ ÖZCAN ${ }^{1}$}

${ }^{1}$ PhD Candidate, Ege University, Department of Philosophy (Orcid ID: 0000-0002-1791-9641)

\begin{abstract}
Özet
Bu çalışmada yapmak istediğim şey Berlin'in "kirpilik", Hegel'in ise "tek-yanlılık" dediği tavrı "ilkesel muhafazakârlık" olarak kavramsallaştırarak bu tutumun eleştirisini eylem ile ilişkisinde ortaya koymaktır. Hegel'in Sofistlere ilişkin çözümlemesi tek-yanlı ilkesel muhafazakârlığın motivasyonlarına, tutarsızlığına ve eylem ile olan uygunsuz ilişkisine dair derin bir perspektif sunar. Kant ahlâkı üzerinde yoğunlaşan öznellik eleştirisi ise her zaman bir çeşitlilik olarak tezahür eden yaşamı tek bir boyuta indirgemenin tehlikelerini aydınlatmanın yanı sıra, tek-yanlıı̆ın izlerini günümüze dek sürmemize imkân tanır. Gelgelim Hegel'in bu eleştirileri tek-yanlılığın doğasını mükemmelen ortaya koymasına rağmen Kantçı düşüncenin zengin dokusunu tam olarak yansıtmıyor gibi görünmektedir. Dolayıııyla Kant ahlâkının tek-yanlıık ve eylemle olan ilişkisine değinmek çalışmanın amaçları dâhilindedir. Böylece, tüm bunların ışığında, eylemin içsel yapısının kendisinden türeyen bir pratik felsefenin düşünceden talep ettikleri belirgin kılınacaktır.
\end{abstract}

Anahtar Kelimeler: Ilkesel Muhafazakârlık, Etik, Ahlâk, Hegel, Kant

Corresponding Author / Sorumlu Yazar

E-mail / E-posta

Manuscript Received / Gönderim Tarihi

Revised Manuscript Accepted / Kabul Tarihi

To Cite This Article / Kaynak Göster
HÜSEYIN DENIZ ÖZCAN

Ege University, Department of Philosophy

huseyindeniz7@hotmail.com

May 29, 2020 / 29 Mayıs 2020

August 07, 2020 / 7 Ağustos 2020

Özcan, H. D. (2020). Bir Eylem Etiği Teorisine Doğru: İlkesel Muhafazakârlığın Eleştirisi. ViraVerita E-Journal: Interdisciplinary Encounters, Sayı 12, 210-234. 


\title{
Towards a Theory of Ethics of Action: Critique of Principal Conservatism
}

\begin{abstract}
In this work, I aim to give a critical account of the attitude referred to by Berlin as "hedgehogness", and by Hegel as "one-sidedness", in connection with action, by conceptualizing it as "principal conservatism". Hegel's analysis of Sophists provides a deep perspective on the motivations and inconsistency of one-sided principal conservatism while also providing an account of its inconvenient relationship to action. Whereas his criticism of subjectivity which concentrates on Kant's morality enables us to keep track of the traces of one-sidedness to this day, as well as shedding light on the hazards of reducing life to a single dimension when it is always manifested as a diversity. Nevertheless, even though these criticisms of Hegel perfectly reveal the nature of onesidedness, they do not seem to provide an accurate reflection of the rich texture of Kantian thought. Hence, the study also aims to address the relationship of Kantian morality with one-sidedness and action. Thus, the demands from thinking of a practical philosophy derived from the inner workings of action will be shown clearly in the light of all the aforementioned factors.
\end{abstract}

Keywords: Principal Conservatism, Ethics, Morality, Hegel, Kant 


\title{
Bir Eylem Etiği Teorisine Doğru: İlkesel Muhafazakârlığın Eleştirisi
}

\author{
“Gerçeklik bize büyüleyici bir tip zenginliğini, geçici bir \\ biçim oyununu ve değişimin bolluğunu gösteriyor: \\ köşesinde oturan zavallı ahlâkçının biri de diyor ki: 'Hayır!' \\ insan başka türlü olmalıydı."
} Nietzsche

\section{Giriş: Kirpiler ve Tilkiler}

"Tilki pek çok şey bilir, ancak kirpi büyük, tek bir şey bilir." Yunanlı şair Arkhilokhos'un bu özlü ifadesinden hareket eden Isaiah Berlin, karakteristikleri ilke ve eylem ile ilişkisine göre belirlenen iki karşıt tip tanımlar (2008, s. 201). Buna göre "tilki" çoğunlukla birbiriyle ilişkisiz, hatta çelişkili hakikatleri bünyesinde barındıran; farklı durumlar karşısında farklı tavırlar takınarak yalnızca çok bilen değil aynı zamanda sınırsız bir çeşitlilik içinde eyleyen kişiye verilen isimdir. "Kirpi" ise bütün evreni yalnızca tek bir evrensel ilkenin ışığında düzenleyen, ne ölçüde farklı olursa olsun yaşamın tüm veçhelerini bu ilkenin merkezinde az ya da çok tutarlı bir sistem olarak örgütleyen ve bu ilke sayesinde a priori olarak hazır bulundurduğu tavrı deneyimleyeceği tüm tekil olaylar esnasında her zaman yanında taşıyan tiptir. Dolayısıyla kirpinin yalnızca tek, büyük bir şey bildiğini söylemek aslında onun her şeyi bildiğini söylemektir. Tüm fenomenler evrenin merkezinde duran bu tek ilkeyle uyum derecelerine göre bir anlam/önem kazanır, onun ışığında yaşar ya da solarlar. Tilki tüm kurnazlığıyla ne ölçüde çeşitlenirse çeşitlensin kirpinin nüfuz edilemez birliği karşısında çaresizdir. Zira hakikate açılan tek pencerenin şahidi olan bu "sihirli göz" onu da kendi sisteminin hazır konumlarından birinin içerisine çoktan sabitlemiştir. Üstelik bu sistem son derece saldırgan ve tehlikelidir: “Çok az şey ... tek hakikate sahip olduğunu düşünen birey ya da gruplardan daha tehlikelidir; özellikle nasıl yaşanacağına, ne olunacağına ve ne yapılacağına dair tek hakikate sahip olduklarında. Bu insanlara göre farklı olanlar yalnızca hatalı değildir, onlar hain ya da delidir; ya kısıtlanmaları ya da bastırılmaları gerekmektedir. Yalnızca kendinin haklı olduğunu düşünmek korkunç ve tehlikeli bir kibirdir..." (Berlin, 2002, s. 345).

Berlin düşünce tarihinin öne çıkan isimlerini oluşturduğu tipoloji ekseninde üstünkörü bir sınıflandırmaya tabi tutar: Söz gelimi Dante, Platon, Dostoyevski, Nietzsche ve Hegel 
"değişen derecelerle birer kirpi"; Aristoteles, Shakespeare, Goethe, Balzac ise birer tilkidirler ( 2008, s. 202). Bu sınıflandırma belli bir ölçüde yapay ve itiraza açıktır -örneğin hakikate ve değişmez ilkelere getirdiği eleştiriler bir yana, tutarsızlığa varan çokanlamlılığı dillere destan olmuş Nietzsche'nin tek ilkeli bir hakikat sisteminin kurucusu olduğuna ikna olmak güçtür. Nitekim Berlin de bu tarz bir ikiliğin fazla üstelenmemesi gerektiğine dair uyarır; önemli olan isimlerin etiketlenmesi değil, bu ayrımın "bakmak ve karşılaştırmak için bir bakış açısı" sunmasıdır (2008, s. 202).

Makalede Kant'ın sözü edilmez. Hegel ise, söylendiği üzere, bir kirpi olarak kodlanır fakat çalışmanın konusu tümüyle başka olduğundan bu iddia temellendirilmez. Aslında bu kategorilerden ilham alarak, Kant'ın ve Hegel'in bir kirpi mi yoksa bir tilki mi olduğuna ilişkin titiz bir soruşturma yürütmek son derece ilginç olurdu. Fakat böyle bir soruşturma ilginç olduğu ölçüde zorlayıcıdır. Bunun tek nedeni Kant ya da Hegel gibi iki büyük filozofun çeşitli dönemlerde ve çok fazla alanda eser vermesi değildir; felsefenin Pantheon'unda yer alan böylesi isimler söz konusu olduğunda, tek bir çerçeve içerisine sıkıştırılmanın önünde engel teşkil eden şey bizatihi düşüncenin çok çeşitli yorumlara imkân veren zengin dokusunun kendisidir. Örneğin yüzeysel bir değerlendirme Kant’ın eşyanın bütününü tek bir transandantal ilke etrafında örgütlediğini zorlanmadan ortaya koyabilir; fakat Saf Aklın Eleştirisi'ne ilişkin yakın bir okumanın, bu kitapta "her şeyi bilinç alanından türetmeyi" reddeden, tüm şeyleri "aklın birliğine indirgemektense ... tutarsızlığı yeğleyen" Kant’ın (Adorno, 2015, s. 71) bir kirpiden ziyade bir tilkiye yakın olduğu görüşü ile sonuçlanması pekala mümkündür. Keza özdeşlik veya çelişmezlik yasalarının kendilerini değil fakat metafizik uygulanımlarını reddeden (Beiser, 2019, s. 215); hakikatin ancak birbiriyle çelişkili veçhelerden oluşan bir bütün olarak kavranabileceğini savunan ve ilk bakışta çok yönlülüğü savunur gibi duran Hegel'in aslında tilki postuna bürünmüş bir kirpi olup olmadığı da aynı ölçüde tartışmalıdır. Fakat bu makalede Kant ya da Hegel'in hakikatini bu soyut kategoriler üzerinde saptamak gibi bir amaç güdülmemektedir. Yapılmak istenen, daha ziyade, ilkelerin eyleme eklemlenme biçimlerinin eleştirisini vermektir. Bir diğer deyişle Kant’ın ya da Hegel'in aslında bir "kirpi" olup olmaması önemli değildir; dikkate şayan olan bugün hâlâ güncelliğini koruyan pratik fenomendir: Bilinçli ya da bilinçsiz olarak, eylemselliği tek ve mutlak bir perspektife indirgemeyi dayatan kirpilik biçimleri vardır ve Hegel'in Kant ahlâkı üzerinde yoğunlaşan eleştirileri bu fenomene dair kayda değer bir şeyler söyler. Hegel söz konusu bu tutumu tek-yanlıık olarak kavramsallaştırır. Şu halde bu çalışmanın amacının tek-yanlıığın eylemle olan uyumsuz ilişkisini ortaya koymak olduğu söylenebilir. 
Elbette tek-yanlılığın esas tehlikesi ilkelerin niceliğinden ziyade niteliğinde; eylemin sabit ve değişmez ilkelerle belirlenmesi yönündeki bir istençle karakterize olan, bu makalede "ilkesel muhafazakârlık" olarak adlandıracağım, yönelimde yatar. Bu nedenle eleştirinin esas hedefi “ilkesel muhafazakârlık” olarak belirlenmiştir. Böylece, Hegel'in yer yer kendi pratik öğretisinin de sınırlarını aşan eleştirileri ışığında, eylemin içsel yapısının kendisinden türeyen bir pratik felsefenin düşünceden talep ettikleri belirgin kılınacaktır.

Başlamadan önce terminolojiye dair birkaç noktayı aydınlatmak faydalı olacaktır. Bu çalışmanın varsaydığı ayrım, Jean-Luc Nancy'nin tabiriyle, "çağımızın tümünün (bazen bulanık bir biçimde de olsa) miras almış olduğu" (2014, s. 189) etik ve ahlâk ayrımıdır. "Aradaki fark şudur: ahlâk eylemleri ve niyetleri aşkın değerlerle ilişkili olarak yargılamaya dayanan özel tipte bir zorlayıcı kurallar bütünü olarak karşımıza çıkar; ... etik yapıp ettiklerimizi, söylediklerimizi dayandığı varoluş kipine göre değerlendiren serbest kurallar bütünüdür" (Deleuze, 2006, s. 114). Demek ki ahlâk eyleme buyruk kipinde sabit ve değişmez ilkeler dayatırken, etik değişebilir ilkelerin eyleme süreç esnasında sürekli eklemlenmesi ile işler. Eylemi deneyimin dışından buyrulan ve deneyim esnasında değişmeyen ilkelerle belirleyen ahlâk aşkındır; etik ise, eylemin kendi yapısından türeyen esnekliğiyle, pratik felsefenin içkin kavranışıdır. Dolayısıyla ahlâktan söz ettiğimizde aşkınlığın, etik söz konusu olduğunda ise içkinliğin imlendiği göz önünde bulundurulmalıdır. Hegel ise, ne sözgelimi Kant gibi tam olarak bir ahlâk ne de kesinlikle Spinoza gibi bir etik filozofudur; onun pratik felsefeye ilişkin konumunu açığa vuran kavram Sittlichkeit’tır. Bu çok özel Almanca sözcüğü, İngilizce çevirisinin aksine, Etik Yaşam olarak değil, Töresellik olarak karşılıyorum. Bunun nedeni Spinoza'nın Ethica'sını "kötü çağrışımlar yaratan" 'Törebilim' sözcüğüyle çevirmek ne kadar uygunsuzsa (Baker, 2015, s. 95), Hegel'in Sittlichkeit’ını "etik yaşam" olarak karşılamanın aynı ölçüde yanlış olmasıdır. Ahlâk ile etik arasındaki ayrım dikkate alındığı takdirde, Hegel'in etikten ziyade ahlâka yakın bir filozof olduğu açıktır: Sittlichkeit’ın Hegelci kavranışı etik bir yaşamdan çok yaşayan bir ahlâka işaret eder. Yine de salt bir ahlâk (Moralität) filozofu olmanın ötesinde bir töresellik filozofu olması Hegel'i içkinlik ile aşkınlık arasında çift yönlü bir diyaloğa imkân veren tuhaf bir sınıra yerleştirir. Onun bu ikircikli konumu sayesindedir ki, Hegel'in soyut ve tek-yanlı olarak nitelediği ahlâka yönelik eleştirileri, eylemin töreselliğinin ötesine geçerek etik bir eylem teorisine doğru uzanan birkaç önermeyi içeriyor gibi görünmektedir. 


\section{Sofistler Neden Kınanır?}

Hegel'in düşünceye eylem ile ilişkisinde atfettiği rol ikirciklidir. Düşünce, belli bir açıdan, pratik alanda oldukça mütevazı bir rol oynar. Hukuk Felsefesi'nin önsözünde belirtildiği üzere, felsefe "grisini gri üzerine boyadığında', yaşamın biçimi çoktan yaşlanmıştır. Ve bu yaşam felsefenin gri üzerine sürülen grisi ile yeniden canlandırılamaz ancak kavranabilir" (Hegel, 2008, s. 16). Bu, düşüncenin sahneye her zaman çok geç çıktığı ve eylemi belirlemeksizin yalnızca eylemin anlamını kavramsallaştırdığı anlamına gelir: Felsefe nasıl sanatı idare edemez, sanatçıya güzel bir eser için formüller, önermeler sunamazsa aynı şekilde ancak bireylerin kolektif çabalarıyla edimselleşen etik ve politik yaşamı da yönlendiremez. Nitekim Hegel'in Tarih Felsefesi'nin önsözünde de tekrarladığı üzere, felsefe "hazır bulunan içeriğe genellik formu giydirmekten başka bir şey yapmaz" (2003, s. 173).

Gelgelim verili tikel içeriğe (spesifik bir halkın edimselleşmiş tinine) düşüncenin tümel formunu vermek (onu felsefenin konusu yaparak bilmek) pratik bakımdan etkisiz olmaktan çok uzaktır. Bu noktada düşüncenin Hegel felsefesindeki çözücü gücüyle karşılaşıyoruz. Hegel'e göre söz konusu bu düşünce edimi biçim ile içerik arasında, içeriksel implikasyonları olan, bir ayrım meydana getirir. Bir halk kendi tinini kavradığında yalnızca yasalarına, adetlerine, ahlâkına ya da sanatına kendine has yüz çizgilerini veren sınırları kavramsallaştırmakla kalmaz, bu belirlenimlerin sınırlılı̆ının da farkına varır. Sınır ötesini imler ve anlama istemeden ayrılmaz: Kendi tininin içinde yeşeren felsefi düşünce, bu tini kendine konu kıldığında onun ötesine geçer; “ahlâk kurallarını ve yaşamın dinçliğini de geride bırakıp refleksiyon ve kavrayışla ilerler. Bunun sonucu şudur ki, bu gerçek, tözsel varoluş türünün, bu ahlâk ve imanın yakasına yapışıp rahatını kaçırır ve böylece yıkım dönemi başlar" (Hegel, 2018, s. 65). Bu toplumsal değişmenin belirleyici noktası ise "şimdide var olan şeyin düşünülmesi ve böylece genelliğe yükseltilmesidir" (Hegel, 2003, s. 180).

Kendi edimsel şimdisini kavrayan düşüncenin bu şimdinin ötesine geçmesi Hegel'in düşünceye atfettiği olumsuz yapıyla doğrudan ilintilidir. Bu tarife göre düşünce olumsuzlamadan ayrı tutulamaz; duyular için zaman neyse verili içerik (düşüncenin nesnesi) için düşünce odurii: "[D]üşünce içinde her türlü varlığın, en başta sonlu varlığın ve onun belirli oluşumlarının çözüldüğü en derindeki sonsuz formun kendisidir" (Hegel, 2003, s. 179). Tam da bu nedenle felsefe, toplumsal değişimin gerçekleşmesinde aktif bir rol oynayan, özsel bir olumsuzlama unsuru içerir. Kendi içsel yapısı uyarınca hareket eden ve gerçekleşmiş sosyal 
düzenlerin geride bırakılan ilkelerini içererek aşan özsel düşünceye verilen ad "Kavram"dıriii: “Kavram tam da Herakleitos'un daimi değişimidir, harekettir, hiçbir şeyin dayanamadığı yakıcılıktır. ... İster doğal Varlığın bir sağlamlığı olsun, ister belli kavrayışların, ilkelerin, geleneklerin ve yasaların sağlamlığı olsun, bu sağlamlık sallanmaya başlar ve dengesini yitirir. ... Bu hareketin, ilk defa ... Sofistler denen kişilerde ortaya çıktığını görüyoruz" (Hegel, 2018, s. 319).

Demek ki Sofistler tam da toplumsal değişimin eşiğindeki dengesiz bir dönemin çocuklarıdır ve çözülüşün atmosferinden beslenen felsefeleri Yunan ethos'u içinde o ana dek benimsenmiş teamülleri temelinden sarsmaya yöneliktir. Onların kınanmasının temelinde değişimden duyulan rahatsızlık yatar. Bu kınama konumuz açısından önemlidir; zira Hegel'in Kavramın hareketinin sözcüsü olan Sofistler ile bu hareketin yarattığı değiş̧imden memnun olmayan sıradan anlayışın ilişkisini ele alan çözümlemesi tek-yanlılı̆̆ın doğasına ilişkin zengin bir malzeme sunar.

Hegel Sofistlerin kavram düzeyinde ifade ettiği değişimden duyulan rahatsızlığı şu şekilde nitelendirir: "kendine başka nasıl yardım edeceğini bilemeyen sağlıklı insan anlamasının [Verstand] kınaması" (2018, 321). Bu ifadedeki alaycı ton, salt ironik bir küçümsemenin ötesinde, kavrayışa ilişkin kavramsal bir ayrımı açığa vurur. Sağıklı insanın anlama yetisi (Verstand) Sofistleri, teorik açıdan göreliliğe rasyonel bir zemin teşkil ettikleri, pratik açıdan ise toplumsal yaşama bir düzen getiren ilke ve yasaların zeminini oydukları için kınar. Fakat anlama yetisi soyutluğun yetisidir. Özü hareket olan Varlığın hakikatini hareket halinde yakalamaya muktedir olan Aklın (Vernunft) aksine, anlama yetisi şeyleri soyut tek-yanlılığı içinde görmeye yazgılıdır. Elbette Hegel tüm sabit hakikatleri yadsıyan hareketi bu karışıklık içinde bırakma niyetinde değildir: Yunan ethos'u içerisinde Sofistlere tekabül eden çözülme, görelileşme ve öznelleşme aşaması, Sokrates'e tekabül eden bir diğer momentte aşılarak İyi ilkesi nesnellik formunu kazanmaya yeniden başlayacaktır ( Hegel, 2018, 364). Fakat bu, "sanki dönülen sonuç aynıymış ve eylem gereksizmiş gibi, hareket eden şeyin önceki sağlamlık durumuna alınması değildir" (Hegel, 2018, 319-320). Benimsenmiş ilkeleri sarsan bu olumsuzlama hareketi, hakikatin içeriğinin zenginleşerek ilkelerin çoğalmasına hizmet eder. Yaygın kanıyı şekillendiren sağlıklı anlama yetisi ise, aklın çok çeşitliliği içinde bildiği hakikat açısından yalnızca birer uğrak olan bu yaşam kurallarını mutlak ve sabit bir hakikat olarak kutsallaştırmak durumundadır. Yaşamın hareketiyle örtüşen yıkıcı düşünce "sahip olduğunu zannettiği servete", yani sıkı sıkı sarıldığı tek ve sabit gerçekliğe yöneldiğinde bunu bir tehdit olarak algılayarak çileden çıkmak 
tek-yanlı, soyut anlayışın doğasında vardır. Bu sağlıklı yetinin kendine başka türlü nasıl yardım edeceğini bilememesi bundandır: Onun sağııkıığının altından kendini gösteren, ilkesel muhafazakârlığın başından beri içinde taşıdığı atalet ve saldırganlıktır.

Israr, dayatma, indirgeme ve yargılama... Bunlar tek-yanlılığın fiilleridir. Tansiyon ve agresyon ise yine bu tutuma ayrılmaz refakatçiler olarak eşlik eder: Tek-yanlılık, dünyayı anlamlı bir birlik olarak kuran sabit ilkesi yaşamın kendi çok çeşitliliği tarafından sürekli tehdit edildiği için sürekli gergin ve tetiktedir. Fakat Hegel analizinin en parlak noktasına henüz ulaşmış değildir. Onun bu fenomene dair söylediği en önemli şey şudur: Arşimet noktasını bildiği tek ilkeye taşımanın konforuyla her şeyi bildiğini zanneden tek-yanlılık, aslında kendi hakikatini bile bilmemektedir. Soyut bilincin varoluşunun varsaydığı şey somut gerçekliktir. Dolayısıyla bilinç, ne ölçüde soyut veya tek-yanlı olursa olsun, değişimin ve eylemin yasalarının geçerli olduğu bir gerçeklikte varolmaktadır. Ve bu varoluş alanında, soyut düşüncenin durmaksızın iptal ettiği şey kendi biricik ilkesinden başkası değildir. İlke ihlal edilir çünkü varoluşta söz konusu olan eylemdir: "Sıradan anlayış [Verstand] bu maksimlerini ve ilkelerini sadece kötü eylemlerinde değil, genel olarak eylemlerinde ihlal eder ve eğer rasyonel bir yaşam sürüyorsa, aslına bakarsanız, bu yalnızca daimi bir tutarsızıktır, tek bir kısıtlı davranış maksiminin diğerlerinden koparılarak yerine getirilmesidir" (Hegel, 2018, s. 320).

Bu dar ufuklu rasyonalitenin tutarsızlığı, rasyonelliğin ve tutarlılığın tek-yanlı bir kavrayışından; soyut özdeşlik ilkesine olan koşulsuz adanmışlıktan ileri gelir. Oysa ne eylem ne de olay asla tek bir maksime sığmaz; yaşam, ne kadar yoksullaştırılırsa yoksullaştırılsın, tek bir ilke için fazla zengindir. Tam da bunu bildiği için tek-yanlılığın çocuksu tutumunun karşısına konumlanan deneyimli, olgun kişi karşılaştığı olayı çok-yanlılığı içinde, tüm veçheleriyle ele alır. Demek ki tilki (en azından onun Hegelci yorumu) rasyonelliğe rağmen değil rasyonel olduğu için birbirinden farklı hatta çelişkili maksimleri bünyesinde barındıran tiptir. Sahiden tutarlı ve rasyonel olan odur. Kendini tek bir maksime göre davranmaya adamış kişi ise kendi hakikatinden bile bihaberdir.

Bu noktada Hegel'in uzlaşmaz görünen uçları nasıl ince bir çizgi üzerinde yürüyerek uzlaştırdığının ve bu uzlaşmanın her zaman, özgürlüğün gözünden bakıldığında kayda değer bir şüpheyi içinde barındıran tümel veya tözsel yan lehine sonuçlanmasının bir örneği ile karşılaşıyoruz. Tutarsızlıktaki fark, tutarsızlık farklı koşullar altındaki farklı eyleme biçimlerinin tutarlılı̆̆ına indirgendiği için, birliğin ayrımı olarak ehlîleştirilir. Tikelin varlığını tanıyormuş gibi yapıp onu tümelin bir momenti kılmak Hegel'in genel stratejisidir ve Hegel bu nedenle haklı 
olarak eleştirilebilir ki, çoklukla eleştirilmiştir. Fakat burada amaçlanan Hegel'in değil, Berlin'in "kirpilik", Hegel'in ise "tek-yanlılık" olarak kavramsallaştırdığı fenomenin eleştirisini vermektir. Ve Hegel'in bu tutuma ilişkin muhteşem önermesi, onun gerçeklik ile olan zayıf bağını ortaya koyar: Gerçekten varolan tek-yanlılığın varoluşu değil, yalnızca arzusu ve yanlış-bilincidir. Tekyanlıık baştan sona ironiktir. Kirpi elbette ironi yapmaz -bunun için fazla asık suratlı ve ciddidir (adanmışlığın ciddiyeti)- fakat ironinin nesnesidir. Zira tek-yanlılığa ilişkin ısrarını bile zorunlu olarak çok-yanlı olan varoluşu içerisinden dile getirmektedir.

Eylem bizatihi sabit ilkelerin tutarlı bir savunusunu mümkün kılan zemini ortadan kaldıran şeydir: Soyut anlama yetisinin mutlak hakikat olarak saygı duyduğu ilkeler eylemde farkında olmadan bir kenara bırakılır. Çünkü eylem tanımı gereği kendi-için’dir. “Öte yandan, tek bir maksime göre davranan kişi, kim olursa olsun, kural delisidir ve her şeyi kendisi için ve başkaları için berbat eder" (Hegel, 2018, s. 320; v.b.a). Demek ki yaşamı tek bir ilkeye sığdırmaya çalışan "kim olursa olsun", buna teşebbüs eden Kant bile olsa, bu girişimin gerçeklikte nefes alamayacağı eleştirisinden payını almalıdır. Nitekim Hegel'in Kant ahlâkına yönelttiği eleştirileri bu ahlâkın yaşamıyor olduğu savının çatısı altında toplamak mümkündür. Elbette bu iddia titiz bir irdelemeyi fazlasıyla hak etmektedir fakat bundan önce tek-yanlılığı doğası gereği iptal eden eylem ile çok-yanlılık arasındaki ilişkiyi ayrıntılandırmamız ve eylemin kendi-için olmasının pratik içerimlerini irdelememiz gerekir.

\section{Eylemin Etiği: Kendi-için Eylemin Pratik Felsefeden Talepleri}

"Kendinde-olan" ve "kendi-için-olan" Hegel tarafından bir karşıtık içerisinde kullanılan iki terimdir. Kendinde-olan, Aristotelesçi dynamis ile ilişkili olarak, edimselleşme sürecine henüz girmemiş bir şeyin niteliklerine ancak gücül (potansiyel) olarak sahip olduğu bir hale işaret eder. "Kendi-için-olmak" ise bu gücül niteliklerin varlığın birer belirlenimine dönüşmesi, edimselleşmesidir. "Kendinde-olan" soyuttur; şeyin diğer şeylerle ilişkisinden soyutlandığı, izole bir hal içinde düşünülmesidir. Buna karşılık bu "kendinde-olan", "kendi-için" haline geldiğinde, artık kendiyle ve diğer şeylerle somut ilişkiler içinde durduğu bir gerçeklikten bağımsız olarak varolması ya da düşünülmesi söz konusu değildir. "Kendinde-olan" şeyin gerçekleşmemiş soyut özüyken, "kendi-için olan" varoluşun gereklerine tanımı gereği boyun eğen somut gerçekleşmedir. 
"Kendinde-olan" gerçekleşme öncesindeki bir soyutlamaya işaret ettiğine göre, kendinde eylem, tıpkı yuvarlak bir kare gibi, oksimorondur. Eylem zaten kendinde-olanın gücül niteliklerinin edimselleşme sürecine verilen ad olduğu için tanımı gereği kendi-içindir. Eylemin özüne kayıtlı bu kendi-içinlik vasfı, onun her zaman ilişkilerle örülü somut bir dünyanın içerisinde var olduğu anlamına gelir. Tam da bu nedenle eylem ancak somut ilişkiler içinde düşünülebilir; zira ona karakterini veren içsel yapı en baştan diğer eylemlerin ördüğü bir ağın içinde şekillenmiştir. Bir diğer deyişle, etkileşim ve çokluk eyleme dışarıdan eklenen nitelikler değildir, bunlar onun kendi doğasından ileri gelir. Nitekim Arendt'in de söylediği üzere "tecrit hali, eylemde bulunma melekesinden yoksun olmak demektir" (2016, s. 276).

Eylemi ilişkiselliği içinde düşünmenin mutlak gerekliliği, o halde, eylemin kendi somutluğundan ileri gelir. Somutluğu içerisinde yakalanmayı özellikle talep eden, ilişkiselliği kendi özünde taşıyan bir süreç olarak eylemin pratik içerimleri son derece önemlidir. İlk olarak, eylemin her zaman bir ilkeler çokluğu ile iş gördüğünü söylemek gerekir. Tek bir ilke eylemi başlatmak için bile yeterli değildir. Eylemin gerisinde yatan motivasyonlar çokluğu, eylem somut olarak düşünüldüğünde, ancak bir maksimler çokluğu olarak ifade edilebilir. Buna karşılık tek bir ilke ya da niyete bağlanmadaki ısrar, eylemi başlatan belirlenimler çokluğunu bu çokluğun tek bir yanına indirgemeyi ön gerektirir ve bu edim soyut düşüncenin işidir. Nitekim Hegel de anlamını ve ereğini tek bir niyetin ifadesinde bulan eylem kavrayışının soyutluğunun tümüyle farkındadır: Niyet (Absicht) soyutlama (Abstraktion) ile etimolojik olarak ilişkilidir ve "somut şeyden tikel bir yanın çekip çıkarılmasını imler" (Hegel, 2008, s. 119). Bu işlem aslında sonsuz bir ilişkiler karmaşası olan eyleme evrensel anlamını verdiği ve hukuki düşüncenin ayakta kalabilmesi bu soyutlamaya bağlı olduğu için Hegel seçimini elbette ondan yana kullanır. Fakat kavrayışının kendi niyetlerini aşan derinliği ile şunu söylememize de imkân verir: Eylemi başlangıcına yerleştirilen tek bir ilke ışığında kavramaya çalışan bütün bir düşünce geleneğinin gücünü tüketen, doğası gereği somut olan eylemin kendisidir. Tek bir ilke, bütün bir yaşam bir yana, tek bir eylem için bile yeterli değildir.

Kendi-için eylemin pratik felsefeye dair söylediği çok önemli ikinci şey, ilkelerin niceliğinin ötesinde niteliğine ilişkindir. Eylemin kendi yapısından türetilen ilkeler yalnızca çoğulluğu değil aynı zamanda değişkenliği de zorunlu bir talep olarak ortaya koyar. Düşünürler arasında eylemin bu tekinsiz veçhesini en iyi kavrayanlardan biri şüphesiz, insani meseleler söz konusu olduğunda belirleyici olanın kırılganlık değil belirsizlik olduğunu dile getiren (2016, s. 355), Arendt olmuştur. Fakat belirsizliğin kapsamı Arendt'in vurgusunun ötesine taşınmalıdır; 
zira belirsizlik yalnızca eylemin niyet edilmemiş sonuçlarında değil, bizatihi niyetlerin kendisinde de içerilir.

Arendt eylemek fiilini karşılayan, "birbirinden tamamen farklı fakat ilişkili" iki sözcük olduğunu hatırlatır: Yunanca archein ve prattein, Latince agere ile gerere (2016, s. 277). Archein/agere "başlatmak, harekete geçirmek, hareket vermek" demektir. Bu, basitçe, eylemin başlamasıdır. Prattein/gerere çiftinin ortaya koyduğu şey ise "erişmek, taşımak, katetmektir." Bu fiiller eylemin bir diğer özsel veçhesini, onun bir süreç olma vasfını ifade eder. Eylem, başlangıcı veya ilkesi ne olursa olsun, yaşamın çeşitli düzeylerini kateden heterojen bir süreçtir ve Arendt'in vurguladığı nokta, her zaman başka eylemlerle örülü bir ilişkiler ağını kateden bu süreçte failin kendi eyleminin niyet edilmemiş sonuçlarıyla karşılaşacağı yönündedir. Belli bir noktada başlayan ve öngörülemez bir süreci kateden eylemin, başlangıç esnasında niyet edilmemiş olan sonuçlar doğurması olumsal değildir; kendi-için eylemin doğasına içkin olan etkileşim, Hegel'in tabiriyle, "zorunluluğu olumsallığa, olumsallığı zorunluluğa" çevirir. Bu, eylemin kendi ilkesine ait olan zorunlu sonuçların başka eylemler ile etkileşiminde olumsallaşması ve eylemin başlangıcında içerilmeyen olumsal sonuçların ise zorunlu olarak beklenebilir olması anlamına gelir. Şans faktörü, tıpkı etkileşim gibi, eyleme dışarıdan eklenmez, eylemin başından beri içerdiği şeydir: Eylemek kişinin kendisini şansın ya da şanssızlığın eline bırakması demektir (Hegel, 2008, s. 117-119).

Arendt'in tarifinin Hegel'in özlü formülasyonu ile örtüşmesi tesadüf değildir; zira süreç içindeki eylemin belirsizliği teması tümüyle Hegelcidir -istenirse izleri Aristoteles'e kadar sürülebilir- ve yine Hegelci olan başka bir temaya eklemlenir: Eylemin anlamı "kendini yalnızca eylemi takiben, eylem sona erdiğinde" açığa vurur (Arendt, 2016, s. 281). Bu, Hegel'in “Minerva'nın baykuşu ancak alacakaranlık çöktükten sonra uçar” (Hegel, 2008, s. 16) derken kastettiği şeyden farklı değildir: Eylemin başlattığı olaylar zinciri ancak öngörülemezliği bağrında taşıyan bu tekinsiz süreç sona erdiğinde anlamlandırılabilir.

Demek ki eylem söz konusu olduğunda hiçbir şey sabit değildir; olaylar çığııından çıkabilir, fail başlangıçtaki etkinliğini iptal eden bir baht dönüşüyle, sonunda kendini kendi eylemine maruz kalan bir kurban olarak bulabilir. Eylem tekinsizdir ve niyet edilmemiş sonuçlar doğurur. Bu noktada şu soruları sormamız gerekir: Eğer eylemin anlamı ancak sonda belli oluyorsa eylemin ilkesi neden baştan belli olsun? Eğer eylem kendi anlamını ancak sona erdiğinde ele verecek ölçüde değişken ve öngörülemezse ilkeler neden katı ve değişmez olsun? 
Ve eğer belirsizlik ve değişim eylemde kendi özsel kategorileri olarak içeriliyorsa, ilkelerin belirli ve sabit olması yönündeki bu ısrarın, bu ilkesel muhafazakârlığın kaynağı nedir?

$\mathrm{Bu}$ sorular (ve bunlardan türetilebilecek diğerleri) bir eylem etiği teorisinin kurucu sorularıdır. Üçüncü sorunun hak ettiği cevap titiz bir soybilim çalışmasını kapsar. Zira yaşamın sanki yaşamın dışındaymış gibi görünen bir konumdan yargılanması; bir diğer deyişle, "olan"ı dikkate almayan bir "olması gereken" kavrayışı ya da eylemi hesaba katmayan bir eylem teorisi, "... sonunda yine de belirli bir yaşam tarzının belirtisi olarak kalır" (Nietzsche, 2013, s. 31). Fakat yaşamı aşan talepleriyle karakterize olan bu yaşam tarzının soybilimsel betimlemesi bu çalışmanın kapsamının fazlasıyla ötesindedir.

Illk soru ilkelerin, yukarıda sözü edilen, belirsiz çokluğuna ilişkindir ve kolay savuşturulabilir bir itiraz olarak görülmeye en elverişli olandır. Arendt, tıpkı başlangıcı tek bir niyete indirgenen eylem kavrayışının soyutluğunun farkında olan Hegel gibi, eylemin motivasyonel belirsizliğine ilişkin bir farkındalığa sahiptir. Fakat bu belirsizlik, eylemin sonuçlarının öngörülemezliğinin aksine, bir süreç olarak eylemin yapısına bağlanmaz; "unutuş" ya da "zihin bulanıklı̆̆ı" gibi dışsal nedenlerle ilişkilendirilerek eyleme dair sorumluluğu örtbas etmenin etkili yollarından biri olarak takdim edilir (Arendt, 2016, s. 17). Yukarıda işaret edildiği üzere, bu tavrın gerisinde yatan şey, ahlâkî ve hukuki düşüncenin işler olabilmesi için böyle bir soyutlamanın (ilkeler çokluğundan tek bir yanı çekip çıkararak çokluğu bire indirgeme) elzem olmasıdır. Fakat bu problemi çözmek değil olsa olsa problemin kaynağına inmektir. Eylemin kendi yapısından türeyen bir etik teorisi oluşturmak için yapılması gereken ilk ve en önemli şey düşünceyi ahlâkî ve hukuki biçimlerin boyunduruğunda kurtarmaktır. Eğer ilkelerin belirsizliği unutuş olarak adlandırılacaksa, bu kavramsallaştırmaya çok önemli bir notun düşülmesi şarttır: Unutuş eylemeyi oluşturan şeyin özü dâhilindedir, zira "her tür eylemde unutmak vardır" (Nietzsche 2009, s. 7).

Tek-yanlılık ilkesel muhafazakârlıkla, ilk soru ikincisiyle, iç içedir: Eylemin ve yaşamın karnavalesk çeşitliliğini tek bir veçheye indirgemek ile eyleme kati ve değişmez ilkeler dayatmak arasında soybilimsel bir yakınlık vardır. Oysa özünde bir eylemsellik olan yaşama sabit ilke veya ilkelerin a priori çektiği setler dâhilinde öngörülebilirlik kazandırmaya ilişkin arzuyu hayal kırıklığına uğratan bizatihi eylemin yapısına içkin olan öngörülemezlik niteliğidir. Arendt'in de dediği üzere: "Eylem daima ilişkiler üretir, dolayısıyla yapısında, bütün kısıtlamaları kaldırmaya ve tüm sınırları aşmaya yönelik bir eğilim bulunmaktadır" (2016, s. 279). Şimdi, eylemin doğasında bulunan sınırları aşmaya yönelik eğilimin eylemin başlangıçtaki ilkesine dönmemesi 
için hiçbir sebep yoktur. Elbette eylemin başlayabilmesi için başlangıçtaki belirli bir niyetin olması gerektiği söylenebilir: Katetme sürecinin başlangıca, prattein/gerere'nin archein/agere 'ye olan bağımlılığı açıktır. Gelgelelim böylesi kırılgan ve tekinsiz bir ağ içinde yer alan eylem, varoluşunun yapısı gereği esnek bir kurallar bütünü ile iş görmek durumundaymış gibi görünmektedir. Dolayısıyla eylemin yalnızca niyet edilmemiş sonuçları olabileceğini söylemek yetmez; eylem sürecinde içkin olarak bulunan sınırsız gücün eylemin ilkelerinin değişebilir esnekliğini, bu da demektir ki etiği, doğrudan talep ettiğini de vurgulamak gerekir. Pratik teorinin bu biçimini celbeden, eylemin değişim ve etkileşime açık çoğul yapısının kendisidir.

\section{Kantçı Sonsuzluğun Keşfi}

Hegel'in Kant ahlâkına yönelik eleştirilerini ve Kant'ın tek-yanlılık ile ilişkisini irdelemeye başlamadan önce birbiriyle ilişkili iki noktayı vurgulamamı gerekir. Dikkat edilmesi gereken ilk nokta, Hegel'in Kant ahlâkında değil ahlâkta (Moralität) bir kusur bulduğu için Kant'ı eleştirdiğidir. Kant’ın ahlâk anlayışı en üst düzeyde yetkindir fakat problem ahlâkın en eksiksiz formu söz konusu olduğunda dahi yeterince yetkin bir bakış açısı sunamamasından ileri gelir. Bir diğer deyişle, Hegel'in ahlâk anlayışı Kant ile büyük ölçüde uyuşur fakat Hegel ahlâkın, ahlâkî bakış açısının kazanımları korunarak, aşılması gerektiğini düşünür: Özgürlüğün somut varoluşu ahlâka ancak bir töresellik içinde bağlı kalmaktır. Töresellik, söylendiği üzere, ahlâk-dışılık değil, yaşayan ahlâktır ve kendi başına alındığında soyut olan ahlâkı bir momenti olarak içerir. Bu, vurgulanması gereken ikinci noktadır. Demek ki bir bakış açısı olarak ahlâktaki kusur bir yanlışlık değil eksikliktir. Ahlâk, Tinin büyük projesi olan özgürlüğün gerçekleşmesi sürecinde mülkiyetten sonra gelen ikinci katman; özgürlüğün şimdi içerisinde yeşerdiği "daha yüksek zemin”, bir diğer deyişle öznelliktir (Hegel, 2008 s. 109). Hegel için ahlâk öznellikle özdeştir; dolayısıyla onun olumlu kazanımlarını içerdiği gibi, öznelliğin mutlaklaştırılmasının bağrında bir potansiyel olarak taşıdığı felaketlerin de habercisidir.

Hegel'e göre kendisini ahlâkın veya Kant'ın bakış açısında ortaya koyan sorun iki yönlüdür fakat bu yönlerin birbirleriyle ilişkili olduğunu gözden kaçırmamamı önemlidir. Zira iki eleştirinin de arkasından kendini gösteren olumsallıktan duyulan endişe ve ahlâkın edimselleşmeyeceğine ilişkin korkudur: Kantçı sınırları içerisinde belirlenmiş bir pratik öğretide Hegel'i endişelendiren ödeve uygun eylemin edimselleştirilmesinin olumsallığı ve bizatihi 
ödevin kendisinin olumsallığıdır. Bu iki yön, literatürde, "Motivasyon Eleştirisi" ve "Formalizm Eleştirisi" olarak adlandırıır.

\section{Motivasyon Eleştirisi}

Bu eleştirinin felsefi artalanı Hegel'in itirazlarını salt psikolojik bir bağlamdan çıkararak fenomenolojik bir düzleme dâhil eder. Motivasyon eleştirisinin gerisinde Hegel'in eylem kavrayışının Kant'ınkinden kayda değer ölçüde farklı olması yatar. İki filozof da analizlerine dolaysız veya verili olandan başlar fakat verili olandan anladıkları şey tümüyle farklıdır. Kant’ın eleştirel felsefesinin genel stratejisi, yetilerin saf işleyişini verili iv olanın analizinden çıkarsamaktır. Bu strateji, pratik akıl söz konusu olduğunda, eylemin dolaysız analizinden hareketle saf arzulama yetisinin imkânını ortaya koymaya yöneliktir ve Kant'ın eyleme baktığında gördüğü ilk şey maksimdirv . Pratik Aklın Eleştirisi maksim ile başlar: Maksim eylemin öznel fakat akılsallık biçimini taşıyan ilkesi, "altına birçok kuralın girdiği genel bir isteme belirlemesini taşıyan önerme"dir (Kant, 2014, s. 21). İstemenin içeriği tikel ya da tümel (öznel ya da nesnel) olsun, eylem her zaman aklın mantıksal önermelerin genel biçimini taşıyan ilkeleriyle başlatılır. Bir diğer deyişle, pratik akıl her zaman, arzulama yetisine tümüyle hâkim olmadığı koşulda dahi, işin içindedir; zira eyleme bir yasadan önce verdiği şey bir maksimdir. Saf arzulama yetisinin imkânı buradan türetilir: Maksim istemenin nesnesine (tikel içeriğe) giydirilmiş akılsal biçimdir, arzulamanın bu biçimini "bütün içeriğinden, yani (belirleyen neden olarak) her türlü isteme nesnesinden ayırırsak, geriye genel bir yasa koymanın sırf biçiminden başka bir şey kalmaz. Demek ki akıl sahibi bir varlık kendi öznel pratik ilkelerini ya da ... maksimlerini pratik ilkeler yapanın, yalnız başına bu maksimlerin biçimleri -onları genel bir yasa olarak konmaya uygun kılan biçimleri- olduğunu kabul etmek zorundadır" (Kant, 2014, s. 31).

Sıradan eyleme baktığında bir maksim gören Kant tikel içeriği soyutlayarak bu maksimi bir yasaya yükseltir. Buna karşılık Hegel'in eylem kavrayışında kendini gösteren her şeyden önce bir harekettir. Kant'ın vurgusu eylemin bürokratik yanınadır: eylemi anlamlı kılan belirleyici unsur, pratik aklın daktilosundan çıkan önermeler, kurallar ya da maksimlerdir. Hegel ise eylemi yaşamın gözünden görmeye daha yakındır; ona göre eylemin özü, Fenomenoloji geleneğinin kavrayışıyla uyumlu olarak, yönelimselliktir. Her eylem bir şey için eylemdir; istisnasız her eylemin bir ereği, gerçekleştirmeye çalıştığı tikel bir içeriği vardır ve öznenin ereğinde taşınan bu tikel içerik "eylemin belirleyici ruhu"dur (Hegel, 2008, 120). Tam da bu nedenle tikel içerik 
eylemden soyutlanamaz zira bu içeriği eylemin yapısına dâhil eden şey eylemin yönelimsel doğasının kendisidir.

Öznel doyum ile ilişkisinde düşünülen bütün tikel içeriklerin nihayetinde gelip dayandığı şey mutluluktur. Hegel'in bu noktada tümüyle Aristoteles'i takip ettiğini belirtmek gerekir: Dirimsel bir fenomen olarak eylemi anlamlandırma sürecinde mutluluk arayışı göz ardı edilebilecek bir unsur değildir. Elbette "mutluluk belirlenimleri verili oldukları ölçüde özgürlüğün hakiki belirlenimleri" olamazlar (Hegel, 2008, s. 121-122); mutluluğun tümel iyinin dolayımına girmesi, hakiki özgürlük ile uyum içinde olması gerekir. Hegel buna karşı çıkmaz. Fakat bunu söylemek bir şey, söz gelimi "yaşamı sürdürme" gibi ahlâkî ödevle uyuşan bir edimin ancak "talihin kötü cilveleri ve umutsuz acı, yaşamdan tat almayı büsbütün yok ettiği" takdirde, ancak o zaman, ahlâkî değeri olduğunu söylemek bambaşka bir şeydir (Kant, 2013, s. 13). Tikel arzuların doyumunu ahlâkî değer ile mutlak bir karşıtlık içinde konumlandıran bir pratik öğretinin gerçekliğin topraklarında nefes alma şansı yoktur. Ve bunun nedeni insanların kendi ahlâksızlıklarını kutsayan "eğri odun"lar olmaları değil, böylesi bir ahlâk felsefesinin eylemin yönelimselliğine içkin olan öznel doyumun belirleyiciliğini hafife almasıdır.

Hegel'in itirazı eylemin etkin motivasyonunun (yönelimi başlatan öznel doyum arayışı) bir buyruk olarak biçimlenen tümel yasa ile hep bir çatışma içinde durmak zorunda olmasınadır. Bu çatışma Kantçı tasarım içinde zorunludur, zira Kant ilkeyi ahlâkî değerden yoksun kılan şeyin öznel doyumun kendisi olduğunu açıkça belirtir. Böylesi bir tasarımı mümkün kılansa eylem ile ilkesinin, sanki eylem kendiliğinden bir yönelime sahip değilmiş ve ilkesinin ifadesini bu yönelimin içerisinde bulmuyormuş gibi, birbirinden koparılmasıdır. Eylemin yönelimselliği içinde a priori bir rolü olan arzu nesnesini ikinci plana atarak ilkeyi eyleme dışarıdan buyrulan bir kural olarak düşünmek ilkenin eyleme eklemlenmesinin aşkın biçimidir. Buna karşılık Hegel eylemin ilkesinin eylemin yöneliminden kopartılamayacağını bilir. Tam da bu nedenle ilkeyi eyleme buyrulan bir buyruk olarak değil yönelimin bir ifadesi olarak düşünür. Şimdi pratik felsefenin çözmesi gereken problem ifadesini edimsel eylemin yöneliminde bulan ilkenin nasıl ahlâksal kılınabileceğidir. Bir diğer deyişle, Kant öznenin tikel arzuları ile her daim bir çatışma içinde olan aşkın bir ahlâk tasarlarken, Hegel ahlâkı arzulamanın içkin yollarını arar. Onun istediği tikel arzular ile tümel erekleri iç içe geçirerek aşkınlığın krallığını içkinliğin topraklarında yeşertmektir. Bu proje ise ancak bir töresellik içinde gerçekleştirilebilir.

Motivasyon eleştirisinin arka planı budur. Kant'ın ahlâkî iyinin iradenin tümel istemesi olduğunu saptaması Hegel'in nazarında büyük bir kazanımdır. Gelgelelim ahlâkî bakış açısı, 
tarihsel olarak belirlenmiş tikel bir töz içerisinde gerçekleştirilmeye doğru aşılmayıp mutlaklaştırıldığında ahlâkî eylemin edimselleşmesi, en iyi ihtimalle, olumsallığa teslim edilir. Dahası böylesi bir ahlâkî istemenin, "saf istemenin hiç yeşermemiş kuru yaprakları" olarak kalması neredeyse kesindir; zira eylemin yapısı gereği izini sürdüğü öznel doyum veya mutluluk arayışı ciddiye alınmadığı takdirde geriye kalan tek buyruk şudur: "Ödevin buyurduğunu tiksinerek yap" (Hegel, 2008, s. 123). Bu, ödevi istemenin Kantçı çerçeve içindeki imkânsızlığıdır. Hegel'in motivasyon eleştirisinin sağlam bir felsefi zemini vardır ve eleştiri büyük ölçüde haklıdır. Elbette Kant'ın bu eleştiriye verilen erken bir cevap niteliğinde, ahlâkî bir motivasyon olarak saygıdan ve saygının öğretinin safığını kirletmeyecek şekilde salt akılsal bir tutku (Gefühl) olduğundan bahseden sayfaları söz konusudur (Kant, 2013, s. 16-17; 2014, s. 81-89 ). Fakat bunlar öğretinin en zayıf ve en karanlık sayfalarıdır. Ahlâk yasasına duyulan saygıyı kişinin kendi saygınlığından duyduğu hazdan ayırmaya ikna olsak ya da bu saygının negatif veçhesi olarak kendini küçümsemenin, "sesi en soğukkanlı günahkarı bile titreten ve kendi bakışları karşısında kendini saklamaya zorlayan pratik aklı" egoya işkence etmekten hoşlanan sadist bir süper-ego ile ilişkilendiren yorumları beslediğini göz ardı etsek bile, böylesi muğlak bir "tutku"nun ne ölçüde güçlü bir motivasyon olabileceği belirsiz kalmayı sürdürür.

\section{Formalizm Eleştirisi}

Töresellik içinde edimselleşmeyen bir ahlâka bağı öznenin huzursuzluğu yalnızca kendi doyumuna karşı düşmanca bir tavır takınan ödeve karşı verilen bitimsiz savaştan kaynaklanmaz. Kantçı ahlâkî özneyi huzursuz eden bir diğer şey ödevin kendisinin belirsizliğidir. Hegel'in formalizm eleştirisi başlığı altında dile getirdiği temel itiraz, Kantçı ahlâkın, tam teşekküllü bir ödev ahlâkı olmasına karşın, şu çok temel ve basit soruya cevap vermekten aciz olduğunu dile getirir: Ödevimin bana yapmamı söylediği şey nedir? ( Hegel, 2008, s. 130).

Baştan söylemek gerekirse Hegel'in bu eleştirisi, ilk eleştirisin aksine, felsefi olarak güçlü bir eleştiri değildir. Hegel'in savı töreselliğin bakış açısına geçmeyip ahlâkî bakış açısında diretildiği takdirde elimizde kalan tek şeyin içi boş bir yasa olacağı ve ahlâkın salt bir "ödev uğruna ödev" retoriğine indirgeneceği yönündedir (Hegel, 2008, s. 131). Bu durum bizi iki sorun ile yüz yüze bırakır: Ödeve uygun eylemi belirlemenin imkânsızlığı ve iyilik istencinden kötülüğe doğru dolaysız bir geçişin imkânı. Aslında iki belirlenim de Kant ahlâkı için tam olarak uygun değildir. Fakat öznelliğin ya da vicdanın mutlak ölçüt olarak kabul edildiği takdirde iyiliğin 
kötülüğe dönüşebilirliği teması, Kantçı ahlâkın hakikatini yansıtmasa da, tek-yanlılığın tehlikelerine ilişkin derin bir kavrayış sunar. Bu noktada kayda değer olan Hegel'in Kant eleştirisi değil, Kant ile ilişkilendirilen tutumun eleştirisidir.

Hegel'in biçimsel yasanın boşluğu eleştirisine karşı birden fazla alternatif savunma geliştirmek mümkündür. Söz gelimi Wood, Hegel ve diğer Alman idealistlerinin Kant ahlâkını formalistik olarak yaftalamalarını, yasanın "amacı tam da bu türden bir formalizmi gidermek olan” diğer iki formülünün göz ardı edilmesiyle ilişkilendirilir (Wood, 2005, s. 173). Burada söz konusu olan, görüye en çok yaklaşan “Özerklik Formülü”nün, birinci formül olan "Evrensel Yasa Formülü"nden daha içerikli olduğu iddiasıdır. Fakat formülleri birbirlerinden içeriksel doluluk derecelerine göre ayırmak pek elverişli bir yol değildir. Zira Kant’’n stratejisinin tümüyle yasanın biçimselliği üzerine kurulması bir yana (bkz. Kant, 2013, s. 45), "Kant’ta özerklik fikrinin en baştan beri evrensellik fikrini içerdiği"ni unutmamak gerekir (Adorno, 2012, s. 119). Fakat yasayı içeriklendirme girişiminin uygunsuzluğuna ilişkin en önemli nokta Kantçı formalizmin böyle bir savunuya ihtiyacı olmamasıdır. Kant ahlâkı, yasasının tüm içeriksizliğiyle, formalizm eleştirisine karşı savunulabilir: Yasa sahiden de boş ve salt biçimseldir fakat ona belirli içeriğini veren yaşamın kendisi olacaktır.

Kant bunu ispatlamak için ahlâk yasasının soyut ve biçimsel tasarımının somutlaştığı örnekler verir. Ve Hegel yine bunun aksini kanıtlamak, yasanın yaşamın somutluğunda özneyi belirsizliğe ve olumsallığa terk ettiğini göstermek için bu örnekleri çürütmeye çalışır. Söylendiği üzere bu karşı çıkış oldukça zayıftır. Söz gelimi Hegel, Kant’ın verdiği emanet para örneğinde (Kant, 2014, s. 31) ahlâk yasasının kesin bir buyruk olarak dile getirdiği, ölen arkadaşımın emanetini yakınlarına teslim etme gerekliliğinin önkoşulu olarak mülkiyeti vurgular: Mülkiyetin kendisinin bir değer olarak kabul edilmediği bir toplumsal düzen içerisinde, ölen dostun emanetini yakınlarına teslim etmenin de hiçbir ahlâkî değeri olmayacaktır. Ve "mülkiyetin olmaması kendi içinde ancak şu ya da bu insanın, ailenin vs. varolmaması ya da tüm insan ırkının yok olması kadar bir çelişki taşımaktadır" (Hegel, 2008, s. 131); bir diğer deyişle bunların hepsi formel bakımdan çelişkisizdir. Kant hâlihazırda mülkiyetin ön-varsayıldığı bir toplum düzeni içerisinden konuştuğu ve bu toplumun kurucu değerlerinin yokluğunun da varlıkları kadar çelişkisiz olduğunun farkında olmadığı için bu ölçüde nettir. Oysa akıl kendi biçimiyle baş başa bırakıldığında yalnızca antinomiler üretir.

Hegel'in itirazı ilk bakışta parlak görünebilir fakat bu yalnızca bir "boncuk oyunu"vidur. Zira Kant’ın örneğinde emaneti teslim etmemi söyleyen yasanın genelliği, mülkiyetin değil, 
güvene ihanet etme ve sözünü tutmamanın kendi içinde taşıdığı çelişkiye dayanır. Nitekim emaneti yerine teslim etmeyen kişinin çiğnediği şey, mülkiyet hakkından önce, dostun güvenidir ve güven tanımı gereği karşılıklı olduğu için “Emanete ihanet etme!” buyruğu mülkiyetin olduğu ya da olmadığı bir düzende aynı ölçüde geçerlidir.

Ahlâk yasasının içi boş biçimselliği ile somut eylemin belli bir içeriği yapısı gereği gerektirmesi arasındaki boşluk abartıldığı kadar büyük değildir. Örnekler çoğaltılabilir fakat yasa içeriğini her durumda bulacaktır. Zira Kantçı yasaya tüm kuvvetini, bir diğer deyişle evrenselliğini, kesinliğini ve aynı zamanda esnekliğini veren şey onun biçimselliğidir. Örnekler kasıtlı olarak en uç noktaya taşınır ve Kantçı ahlâk, yasasının biçimselliğinden değil fakat yaşamın sunduğu tikel içeriğin kendisinden ileri gelen bir belirsizlikle sınanırsa, bu durumda Kant felsefesinin anti-totaliter ruhuna sadık olan bir tilmizin başvuracağı kavram sorumluluk olacaktır. Sorumluluk içi boş biçimsellik ile eylemin yapısından ileri gelen zorunlu içerik arasındaki marjinal yarı̆̆ı kapatan nihai unsurdur: Ahlâkî özne yalnızca ödeve uygun bir eylemden değil, yasanın uygulanımının açık olmadığı durumlarda ödevi olduğunu düşündüğü şeyin yorumundan, boş biçime içerik verme esnasında devreye soktuğu zihinsel kuvvetlerden de sorumludur. Bu, Kantçı özgürlüğün itaat talep eden bir yasanın kasvetinden kurtulup aklın sınırsız kullanımı özgürlüğüne dönüşebildiği noktadır. Zira ahlâkî eylemde açılan estetik bir boyut söz konusudur: Özne kendi yaratıcılı̆̆ından sorumludur.

Kabul etmek gerekir ki bu Kant ahlâkının en dâhiyane anlarından biridir: Eyleme önce gelen bir yasanın mevcudiyetinden şüphe etmek kesinlikle söz konusu olmasa da, yaratıcılık ve sorumluluk gibi birbirine neredeyse düşman kavramların çok tuhaf sentezi sayesinde, özneye hem ahlâkî olma hem de sonsuz çeşitlilik içinde eyleme imkânının açıldığı bir düzlem icat edilir. Burada söz konusu olan kurallarını yaşamın çeşitliği uyarınca sürekli yaratmak zorunda olan bir varoluş estetiği olarak etik (Foucault, 2016a, s. 88) ile katı kurallar bütünü olarak ahlâkın, birbirine karşıt olarak tanımlanan bu iki düşünme ve eyleme biçiminin -tanımlandıkları karşıt sınırlar içerisinde- birbirlerine dokundukları bir temas noktasıdır. Kant adeta yaşamın sona erdiği yerde başlamayan bir ahlâkı icat etmenin bir yolunu bulmuş gibi görünmektedir.

Elbette bu bir anlığına parlayan küçük bir umuttur. Kant düşüncesinin zenginliği böyle bir yoruma imkân verir fakat böylesi bir yorumun bir ahlâka kendi özgün gücünü veren belli nitelikleri sakatlayacağı da göz önünde bulundurulmalıdır. Etik-ahlâk karşıtlığında etiğin handikabı olan bazı komplikasyonların aksine ahlâkın avantajı basitliğidir. Yaratıcılık boyutunun işin içine dâhil edilmesi, ahlâkı, salt bir formasyonun (Bildung) ötesinde, eyleme ilişkin etik 
virtüözlük gibi ekonomik, sosyal, psikolojik vs. koşulların verili adaletsizliği nedeniyle zorunlu olarak seçkinci içerimleri olan kavramlarla ilişkiye sokacaktır. Böyle bir durumda yasanın kendisinin evrenselliği olmasa da ulaşılabilirliğinin evrenselliği tahrip edilir. Kant ahlâkının bu veçhesi merkezileştirildiğinde yitecek olan şey, "sıradan insan aklındaki pratik yargılama gücünün" üstün niteliğine duyulan "hayranlık" (Kant, 2013, s. 19) olacaktır.

Tüm bunların ışığında kesin olan bir şey varsa o da Kant düşüncesindeki zengin dokunun tek-yanlılı̆a direnen çok güçlü bir karşı-kuvvet oluşturduğudur. Kant ilk bakışta, eylemsellik alanının bütününü tek bir ilkeyle katetmeye çalışması ve ilkeleri eyleme aşkın bir biçimde eklemlemesi ile, tek-yanlılığın ve ilkesel muhafazakârlığın emsalsiz bir temsilcisi gibi durur. Fakat onun dehası bu tek ilkeyi kendini sürekli tekrar eden sabit bir reçeteden her durumda farklı yönü gösteren bir pusulaya dönüştürmeyi başarır. Kant’ın mahareti ilkenin sabit tekliği ile eylemin belirsiz çeşitliliğini bir araya getiren bir sentezi mümkün olan en üst yetkinlikte gerçekleştirmesidir. Elbette bu girişimin çıkmazlarının (aporia) peşine düşülebilir. Fakat sonuç ne olursa olsun Kant’ın tek-boyutlu olmak için fazla büyük olduğu fark edilecektir.

\section{Sonuç Yerine: Bir Tek-Yanlılık Biçimi Olarak Vicdan Fetişizmi}

Formalizm eleştirisi Kant ahlâkının hakikatini ortaya sermez fakat bu analize eklemlenen vicdan eleştirisi düşüncenin soyut biçimi ile daima bir arada bulunan tek-yanlılığın saldırganlığına ve tehlikelerine ilişkin çok şey söyler. Hegel'in vicdan eleştirisi temelde Romantikleri hedef almaktadır fakat eleştirinin Kant çözümlemesinin hemen sonrasına yerleştirmesi anlamlıdır. Ahlâk, söylendiği üzere, öznelliğin bakış açısıdır ve öznellik hem yalnızca kişinin kendisi için geçerlilik taşıyan bir kesinlik duygusunu hem de kendisinden başka herhangi bir şeyle temas edip sınanmayı reddeden aklın soyut kullanımını imler. Böylelikle Hegel, Kant ile başlayan soyut öznellik eleştirisinin menzilini Romantik tutuma (kesinlik duygusu) ve Fransız Devrimi'ni karakterize eden düşünme biçimine (soyut akıl) dek uzatır. Elbette Kant düşüncesinin derinlikli yapısı, yukarıda gösterildiği üzere, öznedeki nesnelliği pratik alanda edimselleştirmenin çeşitli imkânlarını sunar. Fakat bu durum Hegel'in soyut akılla ilişkisindeki mutlak kesinlik duygusu olarak vicdana yönelttiği eleştirileri tümden değersiz kılmaz. Vicdanın fetişleştirilmesi, Kant ahlâkının nihai hakikati değil yalnızca yozlaştırılmış bir biçimi olsa da, tek-yanlılığın kusursuz bir örneğidir. Hegel'in Kantçı biçimsel yasanın soyutluğundan duyduğu endişe ne ölçüde yersizse, 
nesnelliğin ölçütleriyle sınanmamış bir öznelliğin bağrında taşıdığı tehlikeden duyduğu korku aynı ölçüde haklıdır.

Vicdan en prestijli öznellik biçimidir. Zira "kendinde ve kendi için iyi olana yönelik bir isteme"yle karakterize olmuştur (Hegel, 2008, s. 132). Bir diğer deyişle, ahlâkî liyiye yönelmek vicdanın doğasında olduğu için, özneye konuşan bu ses diğerleri arasında ayrıcalıklıdır. Gelgelelim zeminini tümel/evrensel l̇yiye yönelik samimi bir kaygıda bulan böyle bir istemenin, tikel çıkarının peşinden koşan sıradan hesapların küçük ve bayağı kötülüklerine kıyasla çok daha büyük felaketlere gebe olması yine bu ayrıcalıktan ileri gelir. Vicdan mutlaklaştırılarak nihai ölçüt haline getirildiğinde menteşelerinden kopar ve lyi gerçeklikten soyutlanarak dar bir perspektife hapsolur. Fetişleştirilmiş vicdan kişinin iyiyi ve doğruyu eylediğine ilişkin bir kesinlik duygusunun yanı sıra, öznenin tasarımına direnç gösteren gerçekliğin dayattığı farklı perspektiflerin bağlayıcılığından sıyrılmış soyut aklı içerir (bu iki unsur tek-yanlılığın doğasını mükemmelen açığa vurur). Daha doğrusu Hegel'in işaret ettiği esas nokta, kendi bakış açısından başka hiçbir şeyi dikkate almayan soyut düşünme biçimine haklılığını veren tek şeyin duygusal kesinlik olduğudur. Bu, eylemini gerçeklikte sınamayan, kendini başka perspektiflere açmayan bir öznelliğin kesinliğidir ve tek-yanlılığın nüfuz edilemezliği dediğimiz şeyi oluşturur: Kişi kendisiyle baş başa kaldığı bu en derin içsel yalnızlıkta kendinden razıysa, eylemlerinin nesnel tezahürleri ne ölçüde yıkıcı olursa olsun onun için bir bağlayıcılık taşımaz; zira böyle bir izolasyon içerisinde duyulan tek ses vicdanın sesidir (krş. Hegel, 2008, s. 133).

Vicdanı hakikatin tek yargıcı olarak atayan bu tutum, kendi doğrusunu salt kendi için belirleyen, kendi halinde bir varoluş tarzı olmaktan çok uzaktır. Tek-yanlılık, yukarıda belirtildiği üzere, nüfuz edilemezliğinin yanı sıra dışlayıcıdır. "Olması gereken"e ilişkin mutlak bir bilgiden "olan"ı yargılamaya geçiş dolaysızdır; zira böylesi bir kapalılık içerisinde yiten şey farklı olanı tanıma kapasitesidir. Fetişleştirilmiş vicdan "öyle bir tapınaktır ki onu çiğnemek kutsalı çiğnemek olacaktır" (Hegel, 2008, s. 133). Dolayısıyla bu vicdanın hakikatine tabi olmayanlara karşı takınılan tavır en iyi ihtimalle acımadır. Kendi hakikatine tapan vicdanın ötekilere yönelik tavrında seçilmişlerin kibrinden izler vardır. Ne olursa olsun mutlaklığı içerisinde vicdan sıradan bir öznellik biçimi olmanın ötesinde, nesnellik iddiasında bulunan ve bu talepte ısrar eden bir öznellik biçimidir; zira "kim kuşku duymuyorsa hakikat avucundadır" (Hegel, 2008, s. 145). Bu durum vicdanı dünyanın yargıcı kılmak için yeterlidir: "Soyut öz-belirlenim ve yalnızca kendi kendinin saf kesinliği olarak bu öznellik hak, ödev ve varoluşun tüm belirlenimlerini kendi içinde kolaylıkla buharlaştırarak aynı zamanda yargılayan bir güçtür..." (Hegel, 2008, s. 134). 
Eğer yargılamadan söz ediyorsak cezalandırmadan da söz etmemiz gerekir. Nitekim "hak, ödev ve varoluşun tüm belirlenimlerini kendi içinde kolaylıkla buharlaştırmak", gerçeklikte adil, düzgün ve iyi olarak edimselleşmiş bütün kazanımların her şeyi kendi mutlak ilkesine göre yargılayan soyut düşünce tarafından bir hiç olarak bulgulanması anlamına gelir. Vicdan tek geçerli hakikatin kendisininki olduğuna yürekten inandığı ve bu hakikati soyut aklının dar ufku sayesinde karşılaştığı her durumda teyit ettiği için gerçekliğin tüm boyutlarını, olumlu veçheleriyle birlikte, yok saymaya belirlenir. Fakat öznenin perspektifine direnç gösteren çeşitlilik, orada, ondan bağımsız olarak vardır. İlkesel muhafazakârlığın hiçbir zaman kendi ilkelerine sıkı sıkı tutunmakla yetinmeyip tüm dünyayı sahiplendiği hakikatine tabi kılmaya çalışması buradan ileri gelir: Gerçeklik olduğu şekliyle, çeşitliliği içinde olmaya bırakıldı̆̆ında ilkenin ayrıcalıklı konumunu kendiliğinden tehdit etmektedir. Böylece yok sayma, yok etmeye dönüşür: Dünyayı tek bir açıdan gören soyut öznellik, yaşam kendi perspektifinin mutlaklığını tehdit ettiğinde yaşam için bir tehdit haline gelir. Bu, vicdan fetişizminin neden "iyiliğin kötülüğe dönüştüğü sınır"da durduğunu açıklar: "ahlâk ve kötülüğün ortak kökleri her şeyden bağımsız olarak bilen ve karar veren bağımsız öz-kesinlikte bulunur" (Hegel, 2008, s. 135).

Kötülüğün bu biçimi, iyiye ilişkin tek-boyutlu bir kavrayışın dizginsiz bir iyilik yapma istenciyle birleşmesinden ileri gelir. Söz konusu olan kötü bir vicdanın ikiyüzlülüğü değil, temiz bir vicdanın çok boyutlu bir ortak yaşam dünyasını tahrip etmesidir. Vicdan yalnız başına hüküm sürmesine imkân tanındığı ve nesnel hiçbir dolayımla sınırlandırılmadığı zaman her şeyi (özneyi ve nesneyi; içi ve dışı) ister. İçe dönük olarak özneden kendisini tek-boyuta indirgeyerek kutsal ereğine adamasını (gerekirse feda etmesini) talep ederken, dışa dönük olarak bütün dünyayı bu kutsal ilke uyarınca dönüştürmenin şiddetini meşrulaştırır ("amaç araçları meşru kılar" (Hegel, 2008, s. 143). Böylelikle çileciliğe yakışan bir ahlâkî adanmışlığın yanı sıra şedit bir politik fanatizmi teşvik ederek keder kültüne iki yönlü bir hizmette bulunur. Bu noktada Hegel'in aklındaki olayın Fransız Devrimi olması şaşırtıcı değildir. Zira tek-yanlıığın ve ilkesel muhafazakârlığın en büyük tehlikesi olan iyiliğin kötülüğe dönüşmesinin içerimleri derinden politiktir.

Fransız Devrimi, diğer birçok şeyin yanı sıra, soyut bir düzenleme ilkesinin yaşamın çok katmanlı ve karmaşık içyapısı karşısında verdiği başarısız bir sınavı ifade eder. Dünyanın verili halinin "eşitlik", "özgürlük" gibi ilkelere uygun olmamasına verilen tepki bir yıkım öfkesi şeklinde tezahür etmiştir. Hegel'in itirazının en anlamlı kısmı soyut bir akıl idesinin yaşama doğrudan dayatılamayacağı, soyut ilkelerin dünyada dolaysız olarak gerçekleştirilemeyeceği yönündedir. 
Tıpkı eylemin kendi doğasının ilkelerin mahiyetine ilişkin belli vasıfları gerektirmesi gibi, yaşamın içyapısı da belli bir eylemsellik tarzını gerekli kılar. Yaşam dünyası ancak gerçekliğin dokusu uyarınca biçimlenmiş düzenlemeleri kabul eder; aksi takdirde müdahale yozlaşmaya mahkûmdur. Nitekim her zaman dolayımlarla işleyen yaşam dünyasının kendi iç rasyonalitesini dikkate almayan ve yaşamı akla uygun olmadığı gerekçesiyle kendi ilkeleri uyarınca düzenlemeye koyulan soyut aklın uygulamaya koyduğu nihai akılsallık biçimi giyotinin geometrik işleyişi olmuştur.

Illkelerin eyleme varoluşun canlı akışından kopuk olarak buyrulmasının dolaysı sonucu yaşamın iç mantığına yabancı bir eylemsellik tarzının dünyaya şiddetle dayatılmasıdır. Şiddet, dolayımlarla işleyen ve kendi iç rasyonalitesine uygun olarak çeşitlenen yaşam ile tek-yanlı, soyut muhafazakârlık arasındaki doğal ilişkidir. Üstelik ilkesel muhafazakârlığın bu tehlikesi her zaman iktidar kanadından gelmek zorunda değildir; ilkelerin eyleme aşkın bir kural olarak eklemlenmesi ve yaşamın, dokusunu tahrip eden bir eylemsellik tarzına maruz bırakılmasının yankıları belli güncel direniş biçimlerinde de duyulabilir. Sözgelimi bugün politik doğruculuk olarak bilinen, sabit, sorgulanamaz ve değişmez soyut ilkelere yönelik mutlak bir sadakatle dünyayı yargılayan ahlâkî tutum, ilkelerini tüm yönleriyle kavrayıp aydınlatmaktan ziyade tek bir boyuta indirgeyerek yaygınlaştırmaya çalışan ilkesel muhafazakârlığın güncel bir örneğidir. Fakat eylemin içyapısını göz önünde bulundurmayan bir pratik öğreti nasıl boşluğa düşmek zorundaysa, yaşamın iç mantığını dikkate almayan bir eylemsellik tarzı da aynı şekilde başarısızlığa uğramak ve çevre-dünyasını kendi başarısızlığıyla birlikte kedere sürüklemek durumundadır. Bu felaketin ölçüsü elbette her zaman ulusal ya da evrensel boyutlarda olmak zorunda değildir; tek-yanlılı̆ın yıkıcı sonuçları yalnızca küçük bir grupla hatta öznenin kendi kendine ettiği zulümle bile sınırlı olabilir. Kederin boyutları ne olursa olsun Hegel bir noktada haklıdır: "kural delisi" olan kişi "her şeyi kendisi için ve başkaları için berbat eder" (Hegel, 2018, s. 320).

Böylece eylemin yapısına uygun olan bir pratik felsefenin nasıl olacağı sorusuna eklemlenen yaşamın yapısına uygun bir direnişin nasıl olacağı sorusudur. Foucault iktidarın soybilimini yaparken, iktidar biçimine ilişkin modern bir dönüşümden söz eder. Buna göre, iktidar bir noktada kararnameler, ilkeler, yasalar buyurmanın ötesine geçmiş ve nüfus üzerinde eşyanın iç mantığına uygun bir etkide bulunma biçimi olarak ortaya çıkmıştır: "Bir yanda doğa, diğer yanda da doğanın üstünde ya da doğaya karşı konumlanan hükümran ve hükümranla kurulması gereken itaat ilişkisi yoktur. Bir nüfus vardır ve bu nüfusun doğası öyledir ki, 
hükümran düşünülmüş yönetim usullerini bu doğanın içerisinde, bu doğa sayesinde ve bu doğaya dair ortaya koymalıdır" (Foucault, 2016b, s. 70). Bugün aynı dönüşümü direniş biçimlerinden talep eden zorunluluk eylemin çok yanlı doğasını dikkate alan bir pratik öğretiyi ön gerektirir. Etik, eylemi bütün canlılığıyla yaşamın gözünden değerlendirdiği gibi yaşamı da eylemselliğin kendi yapısına içkin olan talepleri göz önünde bulundurarak düzenlemeye girişir. Ne kendi öznesinden fanatik bir adanmışlık talep eder ne de "Fiat iustitia, et pereat mundus" diye haykıır. Tek-yanlıığın ahlâkına meydan okuyan şey eylemin etiğidir. Zira etiğin gerisinde yatan tutumu karakterize eden yönelim, kendine uygun olmayan bir dünyayı olumsuzlamaktan önce, canlı ve esnek yapısıyla dokuca uyuşan çok-yanlı bir yaşamı olumlamaktır. Bu olumlamanın hiç de kanaatkâr olmayan sorusu yaşamı, yaşamın olduğu gibi, yani sonsuzca nasıl yaşanabileceği sorunuyla yüz yüze getirmektedir.

\section{ORCID ID}

HÜSEYIN DENIZ ÖZCAN

(iD) https://orcid.org/0000-0002-1791-9641

\section{Declaration of Conflicting Interests}

The author declared that there were no conflicts of interest with respect to the authorship or the publication of this article.

\section{Çıkar Çatışması Beyanı}

Yazar bu makalenin yazarlık veya yayımlanmasına ilişkin olarak hiçbir çıkar çatışması olmadığını beyan etmiştir.

\section{KAYNAKÇA}

Adorno, T. W. (2012). Ahlak Felsefesinin Sorunları. (T. Birkan, Çev.) İstanbul: Metis Yayınları.

Adorno, T. W. (2015). Aşkınsallık Kavramı Üzerine. Cogito(41-42), 56-87.

Arendt, H. (2016). Insanlık Durumu. (B. S. Şener, Çev.) İstanbul: iletişim Yayınları.

Baker, U. (2015). Sanat ve Arzu. İstanbul: İletişim Yayınları.

Beiser, F. (2019). Hegel. (S. Bayazıt, Çev.) İstanbul: Alfa Basım Yayım Dağıtım. 
Berlin, I. (2002). Liberty. New York: Oxford University Press.

Berlin, I. (2008). Kirpi ile Tilki. (Z. Mertoğlu , \& M. Tuncay, Çev.) İstanbul: İstanbul Bilgi Üniversitesi Yayınları.

Deleuze, G. (2006). Müzakereler. (i.. Uysal, Çev.) İstanbul: Norgunk Yayıncılık.

Foucault, M. (2016b). Güvenlik, Toprak, Nüfus. (F. Taylan, Çev.) İstanbul: İstanbul Bilgi Üniversitesi Yayınları.

Foucault, M. (2016a). Özne ve iktidar- Seçme Yazılar 2. (I. Ergüden, Çev.) İstanbul: Ayrıntı Yayınları.

Goethe, J. W. (2013). Faust. (i. Cankorel, Çev.) Ankara: Doğu Batı Yayınları.

Hegel, G. (2008). Outlines of the Philosophy of Right. (T. M. Knox, Çev.) New York: Oxford University Press.

Hegel, G. W. (2003). Tarihte Akıl. (Ö. Sözer, Çev.) İstanbul: Kabalcı Yayınevi.

Hegel, G. W. (2018). Felsefe Tarihi (Cilt I Thales'ten Platona'a Grek Felsefesi). (D. B. Kılınç, Çev.) İstanbul: NotaBene Yayınları.

Kant, I. (2013). Ahlak Metafiziğinin Temellendirilmes. (i. Kuçuardi, Çev.) Ankara: Türkiye Felsefe Kurumu.

Kant, I. (2014). Pratik Aklın Eleştirisi. (İ. Kuçuardi, Ü. Gökberk, \& F. Akatlı, Çev.) Ankara: Türkiye Felsefe Kurumu.

Nancy, J. L. (2014). Heidegger'in Kökensel Etiği. (der) S. E. Er içinde, Heidegger Paris'te (s. 387421). İstanbul: Otonom Yayıncılık.

Nietzsche, F. (2009). Tarihin Yaşam Için Yararı ve Sakıncası. (M. Tüzel, Çev.) İstanbul: Türkiye İş Bankası Kültür Yayınları.

Nietzsche, F. (2013). Putların Alacakaranlığı. (M. Tüzel, Çev.) İstanbul: Türkiye İş Bankası Kültür Yayınları.

Wood, A. W. (2005). Kant. (A. Kovanlıkaya, Çev.) Ankara: Dost Kitabevi Yayınları. 


\section{Sonnotlar}

'Bu tabir Goethe'nin Faust'una bir göndermedir; Mefistoteles şöyle der: “Gridir, dostum, tüm kuramlar/Oysa yemyeşildir yaşamın altın ağacı." Doğu Batı Yayınları’ndan çıkan İclal Cankorel çevirisinde söz konusu kısım: "Renksizdir, değerli dostum, tüm kuramlar..." şeklindedir (Goethe, 2013, s. 99).

ii Zaman değişim ve hareketi bağrında taşıyan spekülatif ilkenin duyusal biçimi, "duyusal olarak algılanabilir olan ilk Oluş formudur." Eğer Herakleitos'un metafizik bir ilke olarak saptadığı şeyi empirik dünyada nasıl tanıdığını sorsaydık "zamandan başka hiçbir şeyden bahsedemezdik" (Hegel, 2018, s. 262).

iii Hegel'in terminolojisinde "kavram" bir şeyi o şey yapan özdür. Hegel, tıpkı Aristoteles gibi, biçimsel neden ve ereksel nedeni birleştirerek öze hareketli bir yapı atfeder ve bu iki nedenin birliğini "Kavram" olarak adlandırır.

iv Bu noktada "verili olan" geleneksel anlamında değil etkin bir aklın kendiliğinden, zorunlu olarak ürettiği ve karşımda bir veri olarak bulduğum şey anlamındadır.

v "Maksim, istemenin öznel ilkesidir; nesnel ilke (yani akıl arzulama yetisine tam egemen olsaydı, bütün akıl sahibi varlıklar için öznel olarak da pratik ilke işini görecek ilke) ise, pratik yasadır" (Kant, 2013, s. 16).

vi Alm. Glasperlenspiel: Teorik ve soyut bakımdan güçlü görünen fakat pratik açıdan tümüyle uygunsuz tasarım. 